\title{
STUDIES OF GLYCERYLPHOSPHORYLCHOLINE DIESTERASE IN THE FEMALE REPRODUCTIVE TRACT
}

\author{
J. C. WALLACE AND I. G. WHITE \\ Department of Veterinary Physiology, University of Sydney, Sydney, Australia
}

(Received 24th Fuly 1964)

\begin{abstract}
Summary. The occurrence of an enzyme which hydrolyses seminal glycerylphosphorylcholine (GPC) has been demonstrated in uterine rinsings of the ewe, cow, sow, rat and mouse. The products of the breakdown of GPC by rinsings of the ewe's uterus, which also contain an active phosphatase, are glycerol, inorganic phosphate and choline. Lower levels of GPC diesterase activity were also found in the cervical and oviduct fluids of the ewe. No diesterase activity could be demonstrated in the follicular fluid of the ewe, which contained appreciable concentrations of lactic acid and glucose.

Secretion of the diesterase in the ewe is influenced by the stage of the oestrous cycle independently of changes in other luminal fluid proteins or the wet weight of the uterus. Diesterase activity in uterine rinsings of the ewe is greatest at the time of ovulation.

The evidence indicates that the enzyme is a product of the uterine tissue and is not of bacterial origin. The optimal $\mathrm{pH}$ is 7.7 and the enzyme is not inhibited by fluoride or eserine.
\end{abstract}

\section{INTRODUCTION}

Increasing attention has been paid in recent years to the secretion and function of the luminal fluids bathing the mucous membranes of the female genital tract. The results of earlier workers on the composition of these secretions have been reviewed by Amoroso (1956) and Olds \& VanDemark (1957a). These and subsequent reports (Ringler, 1956, 1961; Olds \& VanDemark, 1957c, d; Junge \& Blandau, 1958; Howard \& de Feo, 1959; Polge, 1960; Albers \& Castro, 1961; Heap, 1962; Heap \& Lamming, 1960, 1961, 1962; Lutwak-Mann, 1962) indicate the distinctive nature of the luminal fluids and the influence exerted by the ovarian hormones on their secretion.

Other studies suggest that these secretions may influence the activity of spermatozoa (Roark \& Herman, 1950; Olds \& VanDemark, 1957b) and are of importance in the control of uterine infection (Olds \& VanDemark, 1957d; Broome \& Lamming, 1959) and the nutrition of the blastocyst before implantation (Lutwak-Mann, 1959).

Although there have been numerous studies on enzymes of the genital tissues (see Talalay \& Williams-Ashman, 1960; Villee, Hagerman \& Joel, 1960; Gross, 1961, for reviews), there seem to be few reports concerning enzymes in 
the luminal fluid of the female genital tract. However, $\beta$-glucuronidase has been shown to occur in human cervical secretion (Fishman, Kasdon \& Homburger, 1950) and in the rat uterine fluids (Ringler, 1961), peptidase in the uterus during pseudopregnancy (Albers, Bedford \& Chang, 1961), glycerylphosphorylcholine (GPC) diesterase in the uterus of the ewe (White \& Wallace, 1961) and 5-nucleotidase, ATP-ase and purine nucleosidase in rabbit cervical and uterine fluids (Leone, Libonati \& Lutwak-Mann, 1963).

This paper extends earlier observations (White \&. Wallace, 1961; Wallace, Stone \& White, 1964, 1965) on the breakdown of the seminal constituent GPC by the rinsings of the ovine and rat uterus, and indicates the influence of ovarian hormones on its secretion. GPC occurs in high concentration in the semen of a number of species (Dawson, Mann \& White, 1957), but no function has hitherto been ascribed to it. Its enzymatic hydrolysis would, however, make available appreciable quantities of its component moieties, glycerol, phosphoglycerol and choline. The first two are known to be metabolized by spermatozoa in vitro (White, Blackshaw \& Emmens, 1954; Mann \& White, 1956a, b; White, 1957) and might be utilized in the female genital tract.

\section{MATERIALS AND METHODS}

\section{COLLECTION OF FLUIDS}

The genital tract was removed from female animals immediately after slaughter and packed in ice during transport to the laboratory which took about 20 $\min$. The uterine horns were dissected free of fatty and connective tissue and of the attached oviducts and cervix. Calcium-free Ringer phosphate $\mathrm{pH} 7 \cdot 4$ (Umbreit, Burris \& Stauffer, 1959) or 0.134 M-sodium chloride buffered with $0.02 \mathrm{M}$ tris-HCl ( $\mathrm{pH} \mathrm{7.4)}$ was introduced into each horn with a syringe. The fluid was passed along the length of the organ by squeezing or by pressure applied with the syringe and was collected into graduated centrifuge tubes in ice, taking care to avoid contaminating the samples with blood.

The volume of fluid used to rinse each uterine horn or oviduct varied from 0.5 to $8.0 \mathrm{ml}$ depending on the species. A comparison of the recovery of protein from the uterus of the ewe when each horn was rinsed with 2, 4 or $8 \mathrm{ml}$ (four animals/group), showed that total protein recovery was similar when $4 \mathrm{ml}$ or 8 $\mathrm{ml}$ of fluid were used and that both were superior to $2 \mathrm{ml}$. In most experiments on the ewe, therefore, $4 \mathrm{ml}$ was used to rinse each uterine horn. All samples were centrifuged $(1500 \mathrm{~g})$ for $20 \mathrm{~min}$ at 0 to $2^{\circ} \mathrm{C}$ to remove any cell or debris. The amount of such material was small, about $0.2 \mathrm{ml} / \mathrm{uterus}$ in the ewe, and did not seem to vary greatly between stages of the cycle.

The follicular fluid was a pooled sample from a large number of normal, slaughtered ewes kindly supplied by Mr B. J. Restall of the School of Wool Technology, University of New South Wales.

GPC-DIESTERASE ASSAY

Aliquots $(0.5$ to $2.0 \mathrm{ml})$ of the Ringer phosphate rinsings were incubated for periods of up to $15 \mathrm{hr}$ at $37^{\circ} \mathrm{C}$ in the presence of antibiotics $(1 \mathrm{mg} / \mathrm{ml}$ of both penicillin and streptomycin), with or without the addition of about $10 \% \mathrm{v} / \mathrm{v}$ 
seminal plasma as a source of GPC. Seminal plasma was used because it is the normal physiological vehicle for the substrate of uterine diesterase and because, at the time of these studies, the cost of the pure compound was prohibitive. Ram seminal plasma was chosen because it was more readily available than the seminal plasma of other species and because it contains a high concentration of GPC but no phosphorylcholine (Dawson et al., 1957).

The samples were deproteinized by adding 1 vol of $0.15 \mathrm{M} \mathrm{ZnSO}_{4}$ and $1 \mathrm{vol}$ of $0.3 \mathrm{~N}-\mathrm{Ba}(\mathrm{OH})_{2}$. The choline liberated from the GPC by the diesterase was used as a measure of enzyme activity and was estimated in the neutral, deproteinized filtrate as a complex with potassium triiodide, initially by the method of Appleton, Ladu, Levy, Steel \& Brodie (1953) but later by the method of Kushner (1956).

\section{PHOSPHATASE ASSAY}

Uteri were rinsed with $0.134 \mathrm{M}$-sodium chloride buffered with $0.02 \mathrm{M}$-tris- $\mathrm{HCl}$ $(\mathrm{pH} 7 \cdot 4)$. Aliquots of the tris-buffered saline rinsings were incubated in the presence of antibiotics and 8 mM-sodium $\alpha$ - or $\beta$-glycerophosphates or phosphorylcholine. The incubation was terminated after $3 \mathrm{hr}$ by adding trichloroacetic acid to a final concentration of $5 \%$ and the inorganic phosphate liberated was determined by the method of Allen (1940).

\section{GHEMICAL ANALYSES}

GPG was estimated as acid-labile choline by the method described by Dawson et al. (1957).

The protein content of the uterine rinsings was determined by the biuret method (Wales, Scott \& White, 1961), or by measuring the optical density at $210 \mathrm{m \mu}$ (Tombs, Souter \& Maclagan, 1959) after preliminary observations had confirmed the applicability of the latter technique to this biological fluid.

Total reducing sugar was estimated by Somogyi's (1952) modification of the Nelson (1944) colorimetric method. Fructose was estimated by the method of Mann (1948) with an incubation period of $20 \mathrm{~min}$ for colour development (White, 1959).

The specific glucose-oxidase procedure of Huggett \& Nixon (1957) was used for determining glucose. The other methods employed in the analysis of follicular fluid are given in the paper by Scott, Wales, Wallace \& White (1963).

\section{UTERINE TISSUE HOMOGENATES}

The rinsed uterine horns were cut into 1 to $2 \mathrm{~cm}$ segments and homogenized in a Waring blender in $9 \mathrm{vol}$ of Ca-free Ringer-phosphate at $0^{\circ} \mathrm{C}$ for 2 to $3 \mathrm{~min}$. The coarse particles and debris were removed by centrifugation ( $300 \boldsymbol{g}$ for 5 $\min$.

\section{CHROMATOGRAPHIC DETERMINATION OF GPC BREAKDOWN}

Chromatographic evidence for the breakdown of GPC was obtained in the following manner: $8 \mathrm{ml}$ of tris-buffered saline rinsings of sheep uteri were incubated in the presence of antibiotics for $15 \mathrm{hr}$ with $0.8 \mathrm{ml}$ of ram seminal 
plasma. Aliquots $(4 \mathrm{ml})$ taken before and after incubation were heated at $100^{\circ} \mathrm{C}$ for $90 \mathrm{sec}$ and mixed with $6 \mathrm{ml}$ of absolute alcohol. The protein-free filtrate was deionized, concentrated and chromatographed by the methods of Dawson (1955). GPC and glycerol were separated by paper chromatography in $80: 10$ : $100 \mathrm{butanol} /($ glacial) acetic acid/water; GPC from phosphorylcholine in $6: 3: 1$ propanol/0.880 ammonia/water (Hanes \& Isherwood, 1949), and GPC and phosphorylcholine from inorganic phosphate and the other phosphate esters, especially $\alpha$-glycerophosphate, with $100: 10: 12$ phenol/glacial acetic acid/ ethanol system (Dawson, 1960). Areas of the relevant chromatograms with Rf's corresponding to authentic markers were eluted with $1: 1$ alcohol/water or water alone and aliquots taken for analysis. Spray tests were also used to detect the compounds on preliminary chromatograms. Glycerol was detected by the method of Trevelyan, Proctor \& Harrison (1950) and phosphate-containing spots were located by spraying with acid-molybdate reagent (Hanes \& Isherwood, 1949) and irradiating with an ultra-violet lamp (Bandurski \& Axelrod, 1951).

GPG and glycerol were estimated by the method of White (1959). Total and inorganic phosphate were determined by the method of Allen (1940).

CLASSIFICATION OF SHEEP GENITAL TRACTS INTO STAGES OF THE OESTROUS CYGLE Both ovaries were examined and the diameters of prominent follicles and corpora lutea were measured. The three categories used were defined as:

Stage 1. Very recently ruptured follicles or blood-spotted eruptions with corpora lutea (4 to $6 \mathrm{~mm}$ ) forming.

Stage 2. No recent ovulations; average corpus luteum pink and 11 to $12 \mathrm{~mm}$ diameter; no follicles.

Stage 3. Fairly prominent follicles ( 8 to $9 \mathrm{~mm}$ ) and only small ( 7 to $8 \mathrm{~mm}$ ) degenerate (yellow) corpora lutea.

Data kindly supplied by $\mathrm{Mr}$ B. J. Restall indicates that these stages correspond to 0 to 2,8 to 14 and 15 to 17 days after ovulation respectively.

\section{STATISTICAL TREATMENT}

The statistical significance of the results has been assessed by the $t$-test or by analyses of variance.

\section{RESULTS}

EVIDENCE FOR THE OCGURRENGE OF GPG DIESTERASE IN UTERINE RINSINGS The ewe

The first indication that GPC was broken down by rinsings of the ewe's uterus was obtained when $0.5 \mathrm{ml}$ of this fluid was mixed with $0.2 \mathrm{ml}$ of ram seminal plasma. There was a highly significant increase in choline after incubation for $3 \mathrm{hr}$ (mean \pm s.e. $=297 \pm 61 \mathrm{\mu g}$ per $\mathrm{ml}$ of rinsings; $t=4.9 ; \mathrm{df}=18 ; P<0.001)$, or for $15 \mathrm{hr}(t=7 \cdot 1 ; \mathrm{df}=17 ; P<0.001)$. The latter results are presented as part of Table 1 and it is clear that by comparison the increases in choline in seminal plasma and the uterine rinsings incubated separately were negligible. 
The rate of increase in choline on mixing the two fluids was approximately constant during $3 \mathrm{hr}$ and could be accounted for almost exactly by the disappearance of equimolar amounts of GPC. Thus for six samples with a mean ( \pm S.E.) of $437 \pm 214 \mu \mathrm{g}$ choline liberated per $\mathrm{ml}$ of rinsings, GPC containing $459 \pm 196 \mu \mathrm{g}$ of choline was lost. This difference was not significant $(t=0.45$; $\mathrm{df}=5 ; P>0.9)$.

Further evidence of GPC breakdown was obtained by chromatography of incubated and unincubated mixtures of seminal plasma and sheep uterine rinsings. An average of $85 \%$ of GPC $(1 \mathrm{mg} / \mathrm{ml})$ disappeared after incubation compared with less than $10 \%$ loss of GPC in seminal plasma incubated alone

TABLE 1

INCREASE IN CHOLINE ON INGUBATING UTERINE RINSINGS AND SEMINAL PLASMA, SINGLY AND IN COMBINATION

\begin{tabular}{|c|c|c|c|}
\hline Species & $\begin{array}{l}\text { Uterine } \\
\text { rinsings }\end{array}$ & $\begin{array}{l}\text { Seminal } \\
\text { plasma }\end{array}$ & $\begin{array}{l}\text { Uterine rinsings } \\
\text { +seminal plasma }\end{array}$ \\
\hline $\begin{array}{l}\text { Sheep } \\
\text { Cattle } \\
\text { Pig } \\
\text { Horse } \\
\text { Dog } \\
\text { Rabbit } \\
\text { Rat } \\
\text { Mouse } \\
\text { Fowl }\end{array}$ & $\begin{array}{c}126 \pm 70 \quad(15) \\
\\
\\
-7 \pm 20 \quad(6) \\
-1 \pm 3 \quad(5) \\
-35 \pm 26 \quad(36) \\
1 \cdot 0 \pm 1 \cdot 8 \quad(4)\end{array}$ & $\begin{array}{c}39 \pm 29 \quad(12) \\
\\
\\
-12 \pm 72 \quad(10) \\
5 \pm 20 \quad(4) \\
44 \pm 50 \quad(7) \\
0 \cdot 3 \pm 1 \cdot 8 \quad(4)\end{array}$ & $\begin{array}{cc}2023 \pm 287 * * & (18) \\
1524 \pm 324 * & (4) \\
936 \pm 300 * & (7) \\
0 \pm 8 & (7) \\
220 \pm 426 & (6) \\
-10 \pm 14 & (5) \\
163 \pm 32 * * & (40) \\
44 \pm 18 * & (20) \\
18 \pm 74 & (5)\end{array}$ \\
\hline
\end{tabular}

Values given as $\mu \mathrm{g}$ choline (means \pm s.E.) for the total rinsings (or the equivalent seminal plasma used) incubated for $15 \mathrm{hr}$ at $37^{\circ} \mathrm{C}$. Number of replicates shown in parentheses.

$\begin{array}{cc}* * \text { Highly significant increase in free choline, } P<0.05 \\ \text { * Significant increase in free choline, } & P<0.01\end{array}$

and a negligible change in the very small amount of GPC-like material in the rinsings. At the same time at least a third of the GPC lost was accounted for by an accumulation of glycerol and inorganic phosphate. The breakdown of GPC in the first instance was, presumably, to $\alpha$-glycerophosphate, which was subsequently hydrolysed to glycerol and inorganic phosphate. Phosphatase activity was subsequently demonstrated in the rinsings using pure phosphorylcholine and both $\alpha$ - and $\beta$-glycerophosphates.

The breakdown of GPC on mixing ram seminal plasma and ewe uterine rinsings was not likely to be due to bacteria since it was unaffected by bacteriostatic concentrations $(1 \mathrm{mg} / \mathrm{ml})$ of both penicillin and streptomycin. Thus, for three samples incubated with and without the addition of antibiotics the mean increases in choline $(163 \pm 95 \mu \mathrm{g} / \mathrm{ml}$ and $182 \pm 91 \mu \mathrm{g} / \mathrm{ml}$ of rinsings $)$ were not significantly different $(t=0.65 ; \mathrm{df}=2 ; 0.5<P<0.6)$. Moreover, the breakdown of GPC by uterine rinsings was not affected by bacterial filtration. Aliquots were taken from five samples (each $6 \mathrm{ml}$ ) of cell-free rinsings for the estimation of diesterase activity and protein content. The remaining rinsings were passed separately by centrifugal force through Hemming bacterial filters (Oxoid) and further aliquots taken for diesterase and protein determinations. 
It is clear from the results (Table 2) that filtration caused little change in either the diesterase or protein content of the rinsings and that the enzyme activity per unit weight of protein in the filtrate was not significantly different from the unfiltered parent material $(t=0.15 ; \mathrm{df}=4 ; 0.8<P<0.9)$.

The increase in free choline, however, was completely abolished by heating the uterine rinsings for $5 \mathrm{~min}$ at $100^{\circ} \mathrm{C}$. Unheated aliquots of rinsings liberated from seminal GPC $654 \pm 80 \mu \mathrm{g}$ of choline per $\mathrm{ml}$ of rinsings (three replicates) during an overnight incubation, while during a similar incubation aliquots of the same rinsings that had been heated gave an increase of only $11 \pm 14 \mu \mathrm{g} / \mathrm{ml}$ of rinsings. The effect of heating was, therefore, highly significant $(t=7 \cdot 82$; df $=2 ; 0.001<P<0.01)$. This suggested that an enzyme, similar to that in liver reported by Dawson (1956), was responsible for the breakdown of GPC by uterine rinsings.

TABLE 2

EFFECT OF BACTERIAL FILTRATION ON THE GPG DIESTERASE ACTIVITY AND PROTEIN CONTENT OF UTERINE RINSINGS OF THE EWE

\begin{tabular}{|c|c|c|c|}
\hline Treatment & $\begin{array}{l}\text { Diesterase activity } \\
\text { ( } \mu \text { g choline liberated } \\
\text { /ml of rinsings) }\end{array}$ & $\begin{array}{c}\text { Protein } \\
\text { concentration } \\
\text { ( } \mu \text { g protein/ml } \\
\text { rinsings) }\end{array}$ & $\begin{array}{c}\text { Diesterase activity } \\
\text { per unit protein } \\
\text { ( } \mu g \text { choline) } \\
\mu g \text { protein) }\end{array}$ \\
\hline $\begin{array}{l}\text { Unfiltered } \\
\text { Filtered }\end{array}$ & $\begin{array}{l}69 \pm 8 \\
64 \pm 16\end{array}$ & $\begin{array}{l}53 \pm 3 \\
50 \pm 4\end{array}$ & $\begin{array}{l}1 \cdot 32 \pm 0 \cdot 14 \\
1 \cdot 31 \pm 0.23\end{array}$ \\
\hline
\end{tabular}

Values are the means ( \pm S.E.) of five replicates. GPC diesterase activity was measured as ug choline liberated from seminal GPC during $15 \mathrm{hr}$ at $37^{\circ} \mathrm{C}$.

\section{Other species}

GPC diesterase was demonstrated in uterine rinsings from the cow, sow, rat and mouse (Table 1), but consistent evidence for its presence in rinsings from the horse, dog, cat, rabbit and fowl was not obtained under the assay conditions used.

THE DISTRIBUTION OF GPC DIESTERASE IN THE GENITAL TRACT OF THE EWE

After preliminary tests had indicated the presence of the diesterase in secretions of the sheep's cervix and oviduct as well as the uterus, an experiment was carried out to determine its relative distribution along the ewe's genital tract. Uncontaminated vaginal fluid could not be obtained in sufficient quantity for the experiment, but the uterine horns and oviducts were rinsed thoroughly with calcium-free Ringer phosphate totalling $8 \mathrm{ml}$ and $5 \mathrm{ml}$ respectively and the viscous secretions of the cervix were collected with a glass rod and dispersed in $5 \mathrm{ml}$ of Ringer phosphate. The results in Table 3 showed that the total diesterase activity per unit protein in the cervical and uterine fluids was very much greater than those of the oviduct and that the amounts of protein recovered from each segment differed significantly from one another.

GPC diesterase activity was demonstrated also in homogenates of washed uterine tissue of the ewe. Although there were significant increases in choline 
when homogenates were incubated without the addition of seminal GPC, there was, nevertheless, a significantly greater increment in each case when the substrate was added. Thus four homogenates had a mean increase of $226 \mu \mathrm{g}$ of choline per $\mathrm{ml}$ when incubated for $3 \mathrm{hr}$ at $37^{\circ} \mathrm{C}$ alone compared with $482 \mathrm{\mu g}$ liberated when seminal GPC was added $(t=2.6 ; \mathrm{df}=6 ; 0.02<P<0.05)$.

No GPC diesterase activity could be demonstrated in a pooled sample of deepfrozen ewe follicular fluid. Other analyses were made on this fluid which was characterized by a high lactic acid content $(99 \mathrm{mg} / 100 \mathrm{ml})$. It also contained appreciable concentrations of orcinol-reactive carbohydrate $(200 \mathrm{mg} / 100 \mathrm{ml})$,

TABLE 3

GPC DIESTERASE ACTIVITY AND PROTEIN CONTENT OF RINSINGS FROM THE UTERUS, CERVIX AND OVIDUCTS OF THE EWE

\begin{tabular}{|c|c|c|c|}
\hline $\begin{array}{c}\text { Segment } \\
\text { of } \\
\text { genital tract }\end{array}$ & $\begin{array}{c}\text { GPC diesterase } \\
\text { activity ( } \mu \mathrm{g} \text { choline } \\
\text { liberated/total rinsing) }\end{array}$ & $\begin{array}{c}\text { Protein } \\
(\mu g / \text { total } \\
\text { rinsing })\end{array}$ & $\begin{array}{c}\text { Diesterase activity } \\
\text { per unit protein } \\
\text { ( } \mu g \text { choline/ } \mu g \text { protein) }\end{array}$ \\
\hline $\begin{array}{l}\text { Uterus } \\
\text { Cervix } \\
\text { Oviducts }\end{array}$ & $\begin{array}{r}2077 \\
504 \\
80\end{array}$ & $\begin{array}{l}5180 \\
2770 \\
1150\end{array}$ & $\begin{array}{l}0 \cdot 38 \\
0 \cdot 19 \\
0 \cdot 07\end{array}$ \\
\hline
\end{tabular}

Values are the means of five replicates. GPC diesterase activity was measured as $\mu \mathrm{g}$ choline liberated from seminal GPC during $15 \mathrm{hr}$ at $37^{\circ} \mathrm{C}$.

SUMMARY OF THE ANALYSES OF VARIANCE

\begin{tabular}{|c|c|c|c|c|}
\hline \multirow{2}{*}{ Source of variation } & \multirow{2}{*}{$d f$} & \multicolumn{3}{|c|}{ Variance ratios } \\
\hline & & GPC diesterase & Protein & $\begin{array}{l}\text { Diesterasel } \\
\text { unit protein }\end{array}$ \\
\hline $\begin{array}{l}\text { Between tracts } \\
\text { Between segments } \\
\text { Uterus } v \text {. cervix } \\
\text { Uterus } v \text {. oviducts } \\
\text { Residual (error) }\end{array}$ & $\begin{array}{l}4 \\
2 \\
1 \\
1 \\
8\end{array}$ & $\begin{array}{r}1 \cdot 4 \\
5 \cdot 6^{*} \\
6 \cdot 3^{*} \\
10 \cdot 1^{*} \\
983,993\end{array}$ & $\begin{array}{r}1 \cdot 7 \\
17 \cdot 6^{* *} \\
12 \cdot 5^{* *} \\
34 \cdot 8^{* *} \\
1,166,862\end{array}$ & $\begin{array}{c}2 \cdot 6 \\
8 \cdot 3^{*} \\
6 \cdot 1^{*} \\
16 \cdot 4^{* *} \\
14,122\end{array}$ \\
\hline
\end{tabular}

The residual mean square is given in italics.

of which $37 \mathrm{mg} / 100 \mathrm{ml}$ was reducing sugar. The reducing sugar was mainly glucose $(27 \mathrm{mg} / 100 \mathrm{ml})$ with only a trace of fructose $(2 \mathrm{mg} / 100 \mathrm{ml})$ and citric acid $(1 \mathrm{mg} / 100 \mathrm{ml})$. The urea $(61 \mathrm{mg} / 100 \mathrm{ml})$ and ammonia $(40 \mathrm{mg} / 100 \mathrm{ml})$ content were high. The total phosphorus concentration was $20 \mathrm{mg} / 100 \mathrm{ml}$, of which $15 \mathrm{mg} / 100 \mathrm{ml}$ was inorganic phosphate.

INFLUENCE OF OVARIAN HORMONES ON GPG DIESTERASE IN UTERINE RINSINGS

\section{The ewe}

The uterine rinsings of the ewe often varied greatly in diesterase activity and it was felt that this may have been a reflection of the different endocrine states of the animals. To test this, the genital tracts of ewes were classified as Stage 1, 2 or 3 of the oestrous cycle (see Materials and Methods), then weighed and 
luminal rinsings were collected using Ca-free Ringer phosphate. Diesterase and protein determinations were carried out on the rinsings. Diesterase activity was highest during Stages 1 and 3 and lowest during Stage 2 of the cycle (Table 4). The wet weight of the uterus and the protein content of the rinsings, on the other hand, were significantly greater during Stage 3 than at either of the other two stages of the oestrous cycle.

Further evidence of the dependence of the diesterase on the hormonal status of the animal was obtained when rinsings of adult and lamb ewes were com-

\section{TABLE 4}

GPG DIESTERASE AGTIVITY AND PROTEIN CONTENT OF UTERINE RINSINGS AND THE WET WEIGHT OF THE UTERUS AT THREE STAGES OF THE OESTROUS GYGLE IN SHEEP

\begin{tabular}{|c|c|c|c|c|c|}
\hline $\begin{array}{l}\text { Stage of } \\
\text { oestrous } \\
\text { cycle }\end{array}$ & $\begin{array}{c}\mathcal{N} o . \\
\text { replicates }\end{array}$ & $\begin{array}{l}\text { GPC diesterase } \\
\text { activity ( } \mu g \\
\text { choline liberated } \\
\text { /total rinsing) }\end{array}$ & $\begin{array}{l}\text { Protein } \\
(\mu g / \text { total } \\
\text { rinsing) }\end{array}$ & $\begin{array}{c}\text { Diesterase activity } \\
\text { per unit protein } \\
\text { ( } \mathrm{Hg} \text { choline } \\
\text { / } \mathrm{\mu g} \text { protein) }\end{array}$ & $\begin{array}{c}\text { Wet } \\
\text { weight } \\
(\mathrm{g})\end{array}$ \\
\hline $\begin{array}{l}1 \\
2 \\
3\end{array}$ & $\begin{array}{l}6 \\
5 \\
6\end{array}$ & $\begin{array}{l}2781 \\
1265 \\
1710\end{array}$ & $\begin{array}{r}744 \\
776 \\
2135\end{array}$ & $\begin{array}{l}3.72 \\
1.34 \\
0.80\end{array}$ & $\begin{array}{l}44 \cdot 3 \\
42 \cdot 1 \\
59 \cdot 5\end{array}$ \\
\hline
\end{tabular}

Values are the means for the number of replicates shown. GPC diesterase activity was measured as $\mu \mathrm{g}$ choline liberated from seminal GPC during $15 \mathrm{hr}$ at $37^{\circ} \mathrm{C}$.

ANALYSES OF VARIANGE OF LOG TRANSFORMED DATA

\begin{tabular}{|c|c|c|c|c|c|}
\hline \multirow{2}{*}{ Source of variation } & \multirow{2}{*}{$d f$} & \multicolumn{4}{|c|}{ Variance ratios } \\
\hline & & GPC diesterase & Protein & $\begin{array}{l}\text { Diesterasel } \\
\text { unit protein }\end{array}$ & $\begin{array}{c}\text { Wet } \\
\text { weight }\end{array}$ \\
\hline $\begin{array}{l}\text { Between stages } \\
\quad 1 v .2 \\
1 \text { v. } 3 \\
\text { Residual (error) }\end{array}$ & $\begin{array}{c}2 \\
1 \\
1 \\
14 \dagger\end{array}$ & $\begin{array}{c}10 \cdot 6 * * \\
20 \cdot 3 * * \\
9 \cdot 4 * * \\
47\end{array}$ & $\begin{array}{l}7 \cdot 6 * * \\
0 \cdot 0 \\
11 \cdot 6 * * \\
594\end{array}$ & $\begin{array}{l}9 \cdot 7 * * \\
1 \cdot 8 \\
18 \cdot 6 * * \\
594\end{array}$ & $\begin{array}{l}3 \cdot 7 \\
0 \cdot 0 \\
5 \cdot 1 * \\
113\end{array}$ \\
\hline
\end{tabular}

$$
\text { ** } P<0.01 . \quad * P<0.05 \text {. }
$$

The residual mean square is given in italics.

$\dagger$ Reduced to 14 because of a missing value inserted in Stage 2 .

pared. Although the protein content of uterine rinsings in the lamb was only slightly lower than in the adult (mean values \pm s.E./total rinsing were $4.0 \pm 1.3$ $\mathrm{mg}$ and $4.2 \pm 1.7 \mathrm{mg}$ respectively), the diesterase activity was very much less (103 $\pm 21 \mu \mathrm{g}$ and $736 \pm 155 \mu \mathrm{g}$ choline liberated per total rinsing respectively).

\section{The doe and bitch}

To test if failure to demonstrate GPC diesterase activity in rinsings from the rabbit uterus may have been due to the endocrine state of the animals, five adult does were injected intravenously with 75 i.u. of human chorionic gonadotrophin (HCG) and killed in the luteal phase after 7 days. The mean protein content of the uterine rinsings $(825 \pm 110 \mathrm{\mu g} / \mathrm{ml}$ of rinsings) was significantly greater than that of an equal number of control rabbits $(208 \pm 42 \mu \mathrm{g} / \mathrm{ml}$ of rinsings) $(t=3 \cdot 2$; 
$\mathrm{df}=8 ; 0.01<P<0.02)$, but there was no increase in the diesterase activity $(t=0.14 ; \mathrm{df}=8 ; 0.8<P<0.9)$. In the second experiment four rabbits were injected subcutaneously with $10 \mu$ g oestradiol-3,17 $\beta$ in peanut oil each day for 3 days and killed on the 4 th day, but there was no evidence of diesterase activity in washings from the uterus or vagina.

Similarly, when six bitches were brought into false heat by injecting $5 \mathrm{mg}$ of stilboestrol in oil intramuscularly followed by oral administration $(1 \mathrm{mg} /$ day for 5 to 7 days) there was no convincing evidence of diesterase activity in the uterine rinsings.

SOME PROPERTIES OF THE GPC DIESTERASE IN UTERINE RINSINGS OF THE EWE Storage of the enzyme

Storage of the uterine rinsings at $-20^{\circ} \mathrm{G}$ for several days caused only a slight and non-significant loss of diesterase activity $(t=1.41 ; \mathrm{df}=3 ; 0 \cdot 2<P<0 \cdot 3)$. When dialysed uterine rinsings were lyophilized a readily soluble active preparation of the diesterase was obtained and this could be stored at $2^{\circ} \mathrm{C}$ over calcium chloride for 12 months with only about $10 \%$ loss in activity.

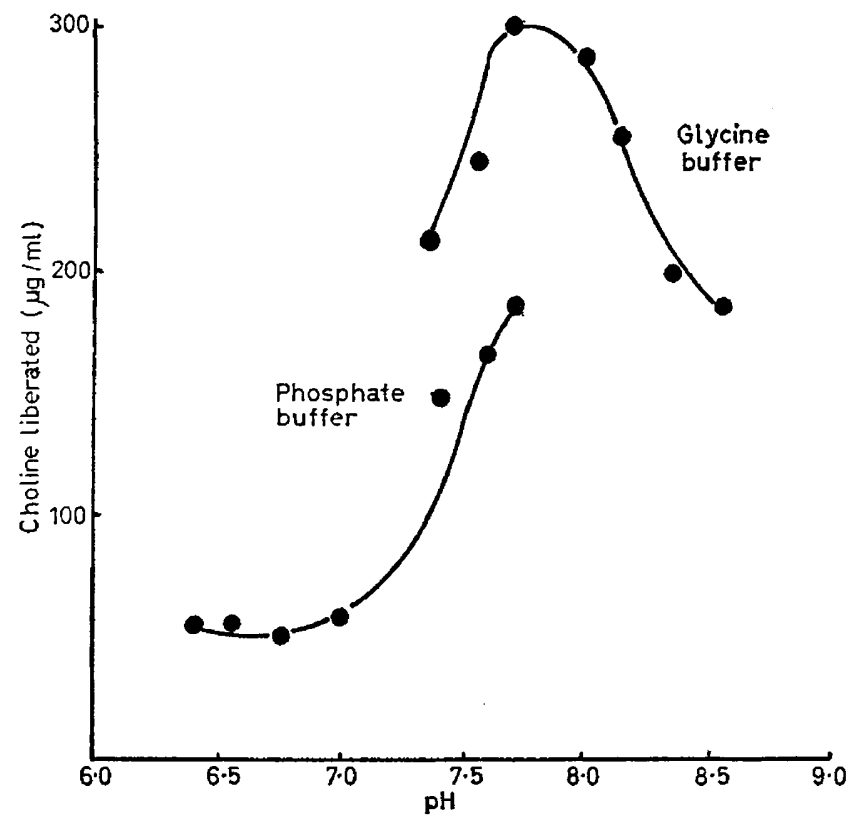

TEXT-FIG. 1. The effect of $\mathrm{pH}$ on the glycerylphosphorylcholine diesterase activity (choline liberated) of rinsings from the ewe uterus.

\section{Effect of pH}

The variation in GPC diesterase activity of fresh uterine rinsings with changes in the $\mathrm{pH}$ of the incubation medium is shown in Text-fig. 1. The activity of $1.0 \mathrm{ml}$ aliquots of Ca-free Ringer rinsings buffered with either phosphate or glycine buffers was measured at $37^{\circ} \mathrm{C}$ over $3 \mathrm{hr}$ at the $\mathrm{pH}$ levels indicated. The buffers were prepared according to Gomori (1955) and were checked with a glass electrode before use. The $\mathrm{pH}$ optimum under these conditions was about 7·7. 


\section{Effect of inhibitors}

Neither fluoride $(0.01 \mathrm{M})$ nor eserine $\left(2 \times 10^{-5} \mathrm{M}\right)$ was found to inhibit the diesterase activity of Ca-free Ringer-phosphate rinsings incubated at $37^{\circ} \mathrm{C}$ for $3 \mathrm{hr}(t=0.1 ; \mathrm{df}=5 ; 0.9<P ;$ and $t=0.5 ; \mathrm{df}=5 ; 0.6<P<0.7$, respectively $)$.

\section{Purification of GPC diesterase}

Solid ammonium sulphate was added slowly with constant stirring to calcium free Ringer-phosphate rinsings at $0^{\circ} \mathrm{C}$ to bring the solution to $25 \%$ saturation with respect to this salt. When the resultant precipitate was centrifuged and dissolved in Ca-free Ringer-phosphate and assayed for diesterase activity, a three- to four-fold increase (three replicates) in activity per unit weight of protein was noted. However, some diesterase activity was also evident in the 25 to $50 \%$ saturation fraction and separation of the diesterase from the $\alpha$ glycerophosphatase in the rinsings had not been achieved as this enzyme showed a fairly similar distribution of activity between these fractions.

\section{DISCUSSION}

The occurrence of a GPC diesterase in the luminal fluids of the female genital tract has greatly extended the scope of a possible physiological role for GPC, a major seminal constituent. The widespread occurrence of GPC in mammalian semen and the coincidence of maximal GPC diesterase activity with mating suggest a significant function. The enzyme could make the glycerol and phosphoglycerol components of GPG available to spermatozoa as an additional energy source in the female genital tract, but the possibility of some more subtle function in enhancing the viability and fertilizing capacity of the spermatozoa cannot be dismissed.

There certainly appears to be no dearth of substrates available to spermatozoa in the female tract. The present studies demonstrate the occurrence of lactic acid and glucose in the follicular fluid of the ewe. Both are metabolized by spermatozoa (see Mann, 1954) and have been reported in the genital tract fluids of other species (Shih, Kennedy \& Huggins, 1940; Lutwak-Mann, 1953; Olds \& VanDemark, 1957c, d; Bishop, 1957).

One possibility, consistent with a preliminary report by Bedford (1961), was that GPC might be the decapacitation factor of semen (Chang, 1957) and hence GPC diesterase the capacitation factor. However, experiments using a GPC diesterase preparation from ewe uterine rinsings gave no indication of causing capacitation of rabbit spermatozoa (I. G White, J. G. Wallace \& M. C. Chang, unpublished data). Failure to demonstrate GPC diesterase activity in rabbit uterine rinsings is further evidence against the enzyme being involved in capacitation.

The distribution of uterine GPC diesterase activity between the various species does not seem to follow any recognizable pattern that might be correlated with the availability of its substrate in semen. GPC occurs in the highest concentration in the semen of the ram and bull, but there are appreciable quantities also in pig, horse, dog and rabbit semen (Dawson et al., 1957). Data are not available for cat semen, but there is chromatographic evidence for the occurrence of 
GPC in the semen of the rat (Dawson \& Rowlands, 1959) and the mouse (J. C. Wallace \& I. G. White, unpublished data). Failure to demonstrate activity in some species however, does not necessarily preclude its occurrence in those cases. Assay conditions may not have been optimal and diesterase activity in the tract may vary with the stage of the oestrous cycle. However, the injection of oestradiol-3,17 $\beta$ or HCG did not induce diesterase activity in the rabbit, nor did the oral administration of stilboestrol have any effect in the dog. The stilboestrol treatment induces anatomical and behavioural signs of oestrus in the bitch but does not, of course, cause ovulation.

The values presented in Table 1 are not necessarily related to the levels of total diesterase activity in the uterine luminal fluids of the various species. The washing procedure may not have removed all the enzyme in each case, since the uteri vary greatly in size and structure depending on the species, and the details of the determinations have been varied slightly according to conditions. It is felt, however, that a more valid comparison can be made within the one species, e.g. for sheep (see Table 4), since preliminary tests indicated the volumes of Ringer used ( $4 \mathrm{ml} /$ uterine horn) gave near maximal recovery of protein.

It would seem that in the reproductive tract of the ewe, the greatest activity of GPC diesterase is in the uterine luminal fluid, that an appreciable amount is present also in cervical secretions, but only low levels occur in the oviduct (Table 3). As in the rat (White, Wallace \& Stone, 1963; Wallace et al., 1964, 1965), the GPC diesterase activity in the uterine rinsings of the ewe is maximal at about oestrus (i.e. Stages 1 and 2 in Table 4 ) and is affected by the ovarian hormones independently of changes in the weight of the organ or in the concentration of the other luminal fluid proteins.

In experiments using organs obtained after slaughter one cannot overlook the possibility that the results may be influenced by the process of killing. Thus Badawy, Campbell, Cuthbertson \& Fell (1957) report the shedding of the intestinal epithelium in sheep and rats following death by a humane killer. In the present studies there was no obvious evidence of the shedding of the epithelium of genital tracts which were obtained within a few minutes of death and the small volume of debris usually obtained after centrifugation suggests that this did not occur. It might also be noted that GPC diesterase activity has been demonstrated in uterine rinsings obtained from the rat (Wallace et al., 1964, 1965) and ewe (J. C. Wallace \& I. G. White, unpublished) under anaesthesia.

In all studies of metabolic reactions in semen and secretions of the female genital tract, the possibility that they may be due to micro-organisms must also be considered. The evidence, however, in the present instance is strongly in favour of the breakdown of GPC being due to an enzyme per se, secreted presumably by the endometrium in response to changes in the hormonal status of the animal. This conclusion is supported by the occurrence of the enzyme in washed uterine tissue, by the failure of antibacterial agents and bacterial filtration (Table 2) to affect its activity, by its induction with oestrogen in ovariectomized rats (White et al., 1963; Wallace et al., 1964, 1965) and in particular its similarity to other mammalian GPC diesterases. Thus the optimal $\mathrm{pH}$ of the 
uterine enzyme (7.7) agrees well with that of Dawson's (1956) liver GPC diesterase which is also not inhibited by fluoride or eserine. The only GPC splitting bacteria described is Serratia plymuthicum and there is no report of its occurrence in semen or the female genital tract. The bacterial enzyme has a much higher optimal pH (9.0) than the uterine enzyme (Hayaishi \& Kornberg, 1954) and since it is bound to the bacterial cell the enzyme would be expected to be removed by filtration if, in fact, it was present in uterine rinsings.

\section{ACKNOWLEDGMENTS}

The authors are indebted to Professor C. W. Emmens for his interest and advice, and to Mr B. Restall, University of N.S.W., for help in classifying genital tracts and supplying follicular fluid. We are grateful to Mr P. Bryden of the N.S.W. State Abattoirs, Homebush, N.S.W., for his co-operation in obtaining genital tracts from ewes, cows and sows, and to Mr J. Keep of the Veterinary Clinic, Sydney University, for his assistance in the experiments on dogs. The work has been aided by grants from the Lalor and Ford Foundations, the Rural Credits Development Fund of the Commonwealth Bank of Australia, and the Wool Industry Fund. One of us (J.C.W.) was supported by a Commonwealth Postgraduate Studentship.

\section{REFERENCES}

Albers, H. J., Bedford, J. M. \& Ghang, M. G. (1961) Uterine peptidase activity in the rabbit during pseudopregnancy. Amer. F. Physiol. 201, 554.

Albers, H. J. \& CAstro, M. N. (1961) The protein components of rat uterine fluid. Fertil. Steril. 12, 142.

Allen, R. J. L. (1940) The estimation of phosphorus. Biochem. F. 34, 858.

Amoroso, E. G. (1956) Implantation. Marshall's Physiology of reproduction, Vol. 2, p. 127. Ed. A. S. Parkes. Longmans Green, London.

Appleton, H. D., Ladu, B. N., Levy, B. B., Steel, J. M. \& Brodie, B. D. (1953) A chemical method for determination of free choline in plasma. F. biol. Chem. 205, 803.

Badawy, A. M., Campbeli, R. M., Cuthbertson, D. P. \& Fell, B. F. (1957) Changes in the intestinal mucosa of the sheep following death by humane killer. Nature, Lond. 180, 756.

BANDurski, R. S. \& Axelrod, B. (1951) The chromatographic identification of some biologically important phosphate esters. F. biol. Chem. 193, 405.

Bedford, J. M. (1961) A study of the decapacitating factor present in rabbit seminal plasma. Fed. Proc. 20, 418.

Brshop, D. W. (1957) Metabolic substrates in rabbit tubular fluid. Int. F. Fertil. 2, 11.

Broome, A. W. J. \& Lamming, G. E. (1959) Studies on the relationship between ovarian hormones and uterine infection. 11. The effect of ovarian hormones on the antibacterial activity of uterine environment. 7. Endocrin. 18, 220.

Chang, M. G. (1957) A detrimental effect of seminal plasma on the fertilizing capacity of sperm. Nature, Lond. 179, 258.

Dawson, R. M. G. (1955) The role of glycerylphosphorylcholine and glycerylphosphorylethanolamine in liver phospholipid metabolism. Biochem. F. 59, 5.

Dawson, R. M. C. (1956) Liver glycerylphosphorylcholine diesterase. Biochem. F. 62, 689.

DAwson, R. M. C. (1960) A hydrolytic procedure for the identification and estimation of individual phospholipids in biological samples. Biochem. F. 75, 45.

Dawson, R. M. G., MANn, T. \& White, I. G. (1957) Glycerylphosphorylcholine and phosphorylcholine in semen and their relation to choline. Biochem. F. 65, 627.

Dawson, R. M. C. \& Rowlands, I. W. (1959) Glycerylphosphorylcholine in the male reproductive organs of rats and guinea pigs. Quart. F. exp. Physiol. 44, 26.

Fishman, W. H., Kasdon, S. G. \& Homburger, F. (1959) $\beta$-Glucuronidase studies in women. 1. Observations in 500 non-pregnant, non-cancerous subjects. F. Amer. med. Ass. 143, 350.

Gomori, G. (1955) Methods in enzymology, Vol. 1. Ed. S. P. Colowick and N. O. Kaplan. Academic Press, New York. 
Gross, M. (1961) Biochemical changes in the reproductive cycle. Fertil. Steril. 12, 245.

Hanes, G. S. \& Isherwood, F. A. (1949) Separation of the phosphoric esters on the filter paper chromatogram. Nature, Lond. 164, 1107.

Hayaishi, O. \& KornBerg, A. (1954) Metabolism of phospholipides by enzymes. F. Biochem. $206,647$.

HEAP, R. B. (1962) Some chemical constituents of uterine washings, a method of analysis with results from various species. 7. Endocrin. 24, 367.

Heap, R. B. \& Lamming, G E. (1960) Studies of the uterine environment of different species. 1. Influence of ovarian hormones on the chemical composition of uterine secretions. $\mathcal{J}$. Endocrin. 20, 277.

Heap, R. B. \& Lamming, G. E. (1961) Studies of the uterine secretion of different species. Proc. IVth int. Congr. Anim. Reprod., p. 300.

HEAP, R. B. \& Lamming, G. E. (1962) The influence of ovarian hormones on some chemical constituents of the uterine washing of the rat and rabbit. 7 . Endocrin. 25, 57.

Howard, E. \& De Feo, V.J. (1959) Potassium and sodium content of uterine and seminal vesicle secretions. Amer. 7. Physiol. 196, 65.

Huggett, A. St. G. \& Nixon, D. A. (1957) Enzymic determination of blood glucose. Biochem. J. 66, $12 \mathrm{P}$.

Junge, J. M. \& Blandau, R. J. (1958) Studies on the electrophoretic properties of the cornual fluids of rats in heat. Fertil. Steril. 9, 353.

Kushner, D. J. (1956) A spectrophotometric microdetermination of choline. Biochim. biophys. Acta, 20, 554.

Leone, E., Libonati, M. \& Lutwak-ManN, C. (1963) Enzymes in the uterine and cervical fluid and in certain related tissues and body fluids of the rabbit. 7. Endocrin. 25, 551 .

Lutwak-Mann, C. (1953) Note on the chemical composition of bovine follicular fluid. J. agric. Sci. 44, 477.

LutwaK-MANn, C. (1959) Biochemical approach to the study of ovum implantation in the rabbit. Mem. Soc. Endocrin. No. 6, 35.

Lutwak-Mann, C. (1962) Some properties of uterine and cervical fluid in the rabbit. Biochim. biophys. Acta, 58, 637 .

Mann, T. (1948) Fructose content and fructolysis in semen. Practical application in the evaluation of semen quality. 7 . agric. Sci. $38,323$.

Mann, T. (1954) The biochemistry of semen. Methuen, London.

Mann, T. \& White, I. G. (1956a) Metabolism of glycerol, sorbitol and related compounds by spermatozoa. Nature, Lond. 178, 142.

Mann, T. \& White, I. G. (1956b) Glycerol metabolism by spermatozoa. Biochem. F. 65, 634.

Nelson, N. (1944) A photometric adaptation of the Somogyi method for the determination of glucose. 7. biol. Chem. 153, 375 .

Olds, D. \& VAnDemark, N. L. (1957a) Physiological aspects of fluids in female genitalia with special reference to cattle-a review. Amer. F. vet. Res. 18, 587.

Or.ds, D. \& VanDemark, N. L. (1957b) The behaviour of spermatozoa in luminal fluids of bovine female genitalia. Amer. F. vet. Res. 18, 603.

Olos, D. \& VanDemark, N. L. (1957c) Composition of the luminal fluids in bovine female genitalia. Fertil. Steril. 8, 345.

Ords, D. \& VanDemark, N. L. (1957d) Luminal fluids of bovine female genitalia. J. Amer. vet. med. Ass. 131, 555.

Polge, C. (1960) Observations on cervical mucus. 7. Reprod. Fertil. 1, 113.

Ringler, L. (1956) Protein composition of rat uterine luminal fluid. Fed. Proc. 15, 152.

Ringler, L. (1961) The composition of rat uterine luminal fluid. Endocrinology, 68, 281.

Roark, D. B. \& Herman, H. A. (1950) Physiological and histological phenomena of the bovine estrual cycle with special reference to vaginal-cervical secretions. Res. Bull. Mo. agric. Exp. Sta. No. 455.

Scotr, T. W., Wales, R. G., Wallace, J. C. \& White, I. G. (1963) Composition of ram epididymal and testicular fluid and the biosynthesis of glycerylphosphorylcholine by the rabbit epididymis. $\mathcal{J}$. Reprod. Fertil. 6, 49.

Shih, H. E., Kennedy, J. \& Huggins, C. (1940) Chemical composition of uterine secretions. Amer. 7 . Physiol. 130, 287.

Somogyi, J. (1952) Notes on sugar determination. 7. biol. Chem. 195, 19.

Talalay, P. \& Williams-Ashman, H. G. (1960) Participation of steroid hormones in the enzymatic transfer of hydrogen. Recent Progr. Hormone Res. 16, 1.

Tombs, D., Souter, F. \& Maclagen, N. F. (1959) The spectrophotometric determination of protein at $210 \mathrm{m \mu}$. Biochem. F. 73, 167.

Trevelyan, I. U. E., Proctor, D. P. \& Harrison, J. S. (1950) Detection of sugars on paper chromatograms. Nature, Lond. 166, 444. 
Umbreit, W. W., Burris, R. H. \& Stauffer, J. F. (1959) Manometric techniques in tissue metabolism. Burgess, Minneapolis.

Villee, C. A., Hagerman, D. O. \& Joel, P. B. (1960) An enzymatic basis for the physiologic function of oestrogens. Recent Progr. Hormone Res. 16, 49.

Wales, R. G., Scott, T. W. \& WhIte, I. G. (1961) Biuret reactive material in semen. Aust. F. exp. Biol. med. Sci. 39, 455.

Wallace, J. G., Stone, G. M. \& White, I. G. (1964) The influence of some oestrogens and progestogens on the activity of glycerylphosphorylcholine diesterase in the rinsings of the rat uterus. $\mathbf{F}$. Endocrin. 29, 175.

Wallace, J. C., Stone, G. M. \& White, I. G. (1965) The effect of the oestrous cycle and of oestradiol on the breakdown of seminal glycerylphosphorylcholine by secretions of the rat uterus. Aust. 7. biol. Sci. (In press).

White, I. G. (1957) Metabolism of glycerol and similar compounds by bull spermatozoa. Amer. $\mathcal{F}$. Physiol. 189, 307.

Whrre, I. G. (1959) Studies of the estimation of glycerol, fructose and lactic acid with particular reference to semen. Aust. F. exp. Biol. med. Sci. 37, 441 .

White, I. G., Blackshaw, A. W. \& Emmens, C. W. (1954) Metabolic and motility studies relating to the low temperature storage of ram and bull spermatozoa. Aust. vet. 7. 30, 85 .

White, I. G. \& WALLACE, J. C. (1961) Breakdown of seminal glycerylphosphorylcholine by secretions of the female genital tract. Nature, Lond. 189, 843.

White, I. G., Wallace, J. C. \& Stone, G. M. (1963) Studies on the glycerylphosphorylcholine diesterase activity of the female genital tract in the ewe, sow and rat. F. Reprod. Fertil. 5, 298. 